\title{
Online Learning Strategies to Reduce Online Gaming: Case Studies in Sidoarjo, East Java, Indonesia
}

\author{
Redi Panuju \\ Department of Communication, University of Dr Soetomo Surabaya \\ Indonesia \\ Email: redi.panuju [AT] unitomo.ac.id
}

\begin{abstract}
This article describes a strategy adopted by elementary and high schools during the COVID 19 pandemic that aims to keep students studying at home and fill their time with assignments to reduce playing online games. This strategy involves assigning teachers to students in collaboration with students' parents, as well as using a personal touch approach. Media used in online learning include Video Calls from WhatsApp, Google Classroom and the Zoom application.
\end{abstract}

Keywords--- Online Game, parent-school collaboration, personal touch, the Covid-19 pandemic

\section{INTRODUCTION}

The Indonesian government adopted a Large-Scale Social Restrictions (PSBB) policy to break the Corona Virus or Covid-19 pandemic chain. Although the first case was confirmed in Indonesia on March 2, 2020, with two (2) Depok residents in West Java Province who tested positive for Covid-19, President Joko W idodo signed Government Regulation No.21 in 2020, which allowed local governments to restrict the movement of people and goods in and out from their respective regions.

The implication is that educational institutions at all levels are prohibited from conducting face-to-face learning activities; instead, the teaching and learning process is carried out using the internet. Students are required to take lessons from their res pective homes, as teachers also give les sons from their respective homes. Popular tools used for the virtual learning process include using the Google classroom application, Zoom or Video Call from the WhatsApp (WA) application.

This method of learning is a relatively new learning model in Indonesia, but inevitably, it must be implemented so that the learning process in schools does not stop. Both parents and children experiencestress or burnout while staying at home. Children's loss of social relationships is primarily what makes themuncomfortable, while parents experience stress because they have to learn to use online applications to help children's learning.

One way children deal with stress during their stay at home is channeling it through online games. This method is the easiest and cheapest option to obtain. Parents are generally forced to let their children fill their free time playing on line games because they are unable to provide other facilities for children to relieve their stress or boredom.

Previously, a lot of research in Indonesia showed that online games are the most popular games for elementary school children. Moreover, because visually these online games are very interesting, they can also interact with friends in the game. According to a study reported by the Faculty of Medicine at Universitas Indonesia, many children are addicted to playing games. Many children play games late in to the night, even untilmorning (02.00 Indonesia Time). Characteristics of social behavior of children who are addicted to playing g ames include reduced socialization with peers and being lazy to take a shower (even chamber pots are brought to the roombecau se they do not want to go to the bathroom). The study concluded that the number of game addicts in Indonesia is thou ght to be the highest in Asia [1]

Another implication froma study conducted by Elizabeth Theresia (2019) of 546 students in Bandar Lampung is that children who are addicted to the online game experience decreased learning motivation [2]

Based on several studies, online games are known to have a positive impact when used as a means of entertainment [3] such as reducing stress and fatigue [4]. Whereas if you have experienced addiction, it will negatively impact the body, mind, emotions and behavior [5]

For children who are still in family protection, the duration of the using gadgets to play online games can be controlled, when the time and type of online games are allowed. However, for children who relatively lack control (because both parents work), these children form their own community and play online games outside the home, e.g. in a coffee shop. The reas on for choosing a coffee shop is because usually a coffee shop provides an internet connection that can be accessed for free. These children play online games in coffee shops with unlimited time. [6]

Lack of communication between parents and children gives children the opportunity to look for an escape in the game and in certain cases, due to the probability of influence of adult bad behavior; these children might consume liquor, which can be particularly hazardous for them [7] 
Thus, during the Covid-19 pandemic, children have the potential to use their gadgets to play games even longer. This is what worries teachers in primary schools so that they come up with ideas or strategies on how to minimize the use of online games' playing time with structured online learning strategies.

\section{METHODS}

This research uses a qualitative approach. The data were obtained through observation of the online teaching and learning process at Raudlatul Jannah Primary School. This school is located in Sidorajo Regency, an area of East Java, Indonesia. As if this is managed by the community with a concentration on the spread of values derived from Is lam. Researchers also conducted interviews with students and teachers at that place. The results of observations and interviews were combined with secondary data obtained from the school's webside

\section{RESULT AND DISCUSSION}

\subsection{Combination of Assignments, Parental Control and Personal Touch}

The learning strategy, which is the subject of this article's review, was taken fromthe Raudlatul Janah Is lamic Elementary School, located at Jalan Jatis ari Permai X Pepelegi, Waru, Sidoarjo, East Java. This school uses a family curriculumthat is processed with a thematic approach. This approach puts more emphasis on the principles or values contained in the teachings of Is lambased on the Holy Qur'an and Hadith [8]

This school has an interesting way of learning during the Covid-19 pandemic, where children must learn from home to avoid transmis sion of the virus. Observations were made during Ramadan (April 24 - May 24, 2020). In general, learning is done using WhatsApp Video Call, Google Clas s Room andZoom. The structure of the schedule allows students to focus on learning; thus, students only have relatively little time to play online games.

The teacher gives as signments to students to open the Google Classroom application. Previously, the teacher had uploaded teaching material in the form of a summary of the material taken from the textbook. The time is also limited, so students really have to try seriously to do it. Students are as ked to answer questions in the form of multiple choices. The next day, the teacher gives feedback in the formof a score of student answers and motivational comments. In this comment, a personal touch is given.

Next, the school invites parents to supervise their children's activities during the month of Ramadan by initialing a monitoring card filled out by students. Several column s must be carried out every day. If this is done, students get a score of 1 and if not, they score zero (0). Activities that are monitored by parents might include; Fasting, five daily prayers ( Fajr, Duhur, Asr, Maghrib, and Isha), Tarawih, Tilawah, Tahidz), Assignments and Life Skills. Fasting is an obligation for every Mus lim to carry out in the form of not eating and drinking and holding back unlawful acts such as anger, stealing, adultery and so on. Prayer (Salat) is the oblig ation of Mus lims to worship their Lord, Allah SWT, five times a day at the appointed time. Tarawih is a night prayer that is held during the month of Ramadan. Tilawah is learning to improve the ability to read the Qur'an correctly [9]. The ability to read the Qur'an continues with the graduation exam. Students are tested in public, and given questions about the laws of reading. This program is often called munaqosah [10]. The graduation results are announced in a specific speech called imtihan. Tahfidz is the activity of memorizing the Qur'an with certain learning methods [11]

Assignments are instructions from the teacher to students to carry out certain activities. For example, students are asked to take pictures of activities that dis play helping each other in the community.

Life Skill is an activity of students doing simple things that are useful in their respective homes; for example, helping parents s weep the yard, wash motorbikes, feed fish and cats, and the like.

\subsection{1 Assignments}

Teacher assignments to students above the accumulation score are calculated by themselves and initialed (signatured) by the students' parents. The success of this learning strategy relies on the honesty of children and parents in recording activities. If parents feel unable to control the child, it is usually communicated to the teacher to do coaching in school. Even to give a deterrent effect on children, the school calls students' parents. Together with parents, the child will confirm his or her honesty. In this way, it will usually open up problems experienced by students in carrying out schoolwork. The teacher will then ask students to improve and make a statement of self-improvement that is supervised by parents.. That's the collaboration strategy between assignment, parental control and personal touch. 
Figure 1. Student Activity Control Card, which is controlled by the school and parents (s ource: personal documentation )

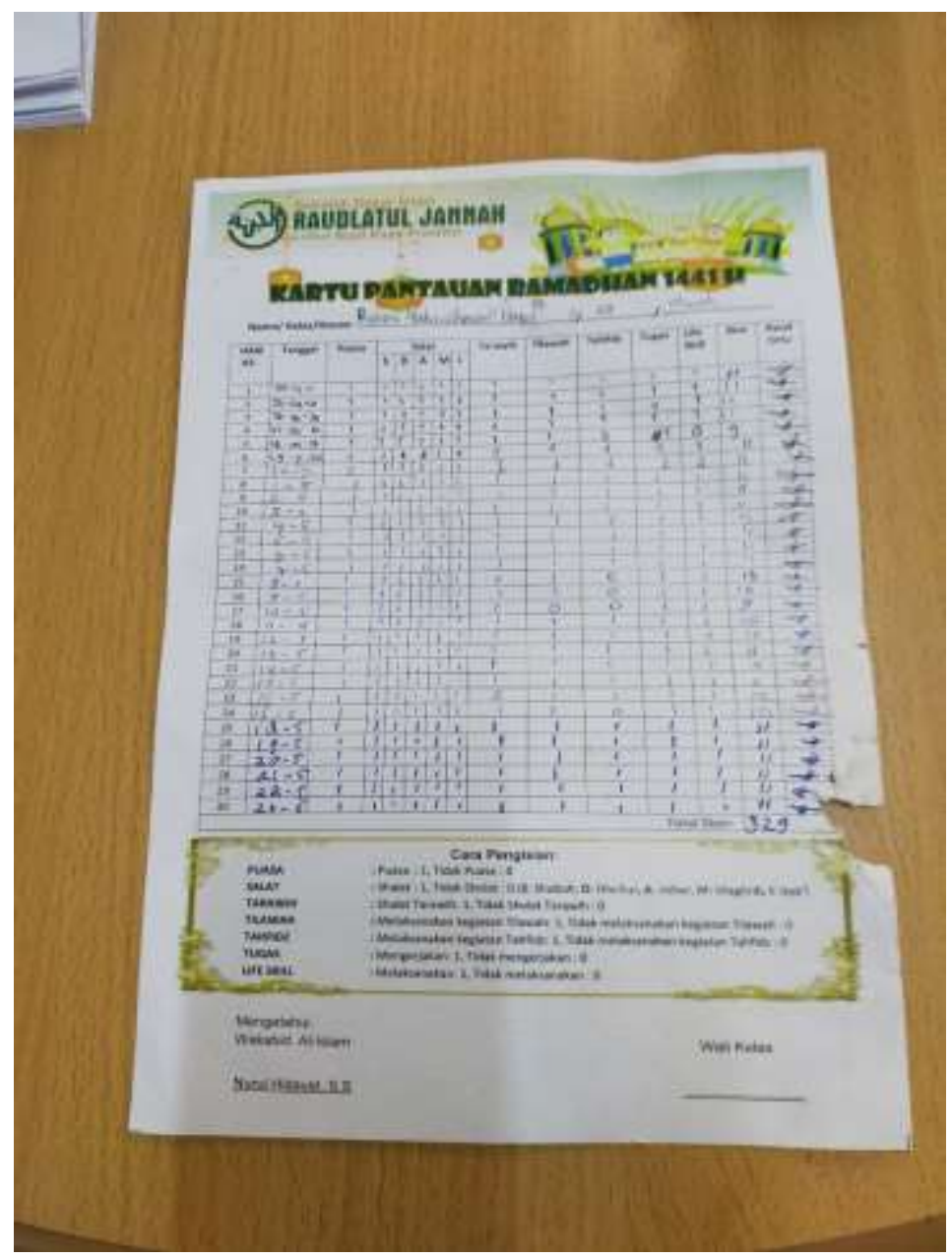

\subsection{Parent home visit}

The school as signs the teacher to vis it the home of the parents of students to do questions and answers with the parents of students. Questions focused on the obstacles faced by children and parents in learning through online. Information was obtained that there are some parents who experience difficulties because they do not or have not mas tered internet-based learning technology. According to the school, to overcome this, the school provides technical training through web seminars on certain days, for example on Saturdays where it is likely that parents are off from work so they have time to attend. In addition to parents, questions were also addressed to students. At first the children admitted to experiencing boredom learning via the internet, so they often did not attend. As a way to overcome boredom, students admit to playing online games. Then the teacher formed a WhatsApp Group which specifically consisted of students in their respective clas ses. It is through this group that the teacher gives a touch of emotion which contains motivating students to retum to online clas ses.

\section{CONCLUSION}

The Covid-19 pandemic era strengthens the tendency of students to spend their time playing online games. Before the outbreak of this outbreak, students were suspected of having a habit of playing online games. They play alone (Solo) or form their own groups. This habit is feared to lead to addiction to playing games, thereby reducing his concentration in learning, moving away from the community, and creating unharmonious relationships with his family. especially parents expect their children to be diligent in learning and succeed in studies. Based on this research, Raudlatul Jannah Elementary School in East Java, Indonesia, has succeeded in reducing the frequency and intensity of thehabit of playing online games among its students with a combination of as signments, parental control and personal touch, a combination of assignments, an The school as signs the teacher to visit the home of the parents of students to do ques tions and answers with the parents of students. 


\section{REFERENCES}

[1] Siste, K. (2020). Jumlah Pecandu Game Online di Indonesia Diduga Tertinggi di Asia. Accessed from https://fk.ui.ac.id/infosehat/jumlah-pecandu-game-online-di-indonesia-diduga-tertinggi-di-asia/ ， Jakarta, Indonesia

[2] E. Theresia, O.R. Stiawati.O.R, N.P. (2019) Sedyatyani. Hubungan Kecanduan Bermain Game Onlie dengan Motivasi Belajar Pada Siswa SMP di Kota Bandar Lampung Tahun 2019//Psyce: Jurnal Psikologi No.1(2). https://doi.org/10.36269/psyche.v1i2.103, Jakarta, Indonesia, 96-105

[3] E. Adams. Fundamental of Game Design ( $2^{\text {nd }}$ ed). (2013). New RidersPublishing. New York, USA

[4] Ros soniello, O’Brien \& Park. Russoniello, M. (2009). The effectiveness of casual

video games in improving mood and decreasing stress. Journal of Cyber Therapy \& Rehabilitation. No 2(1). Italia, 53-66.

[5] E. Novriyandi. Online Game Addiction in Adolescents: Impacts and its Prevention. (2019). Buletin PsikologiNo.27 (2) 148-158., Jakarta, Indonesia http://doi.org/10.22146/buletinpsikologi.47402

[6] R. Panuju. PERILAKU MENGAKSES INTERNET DI WARUNG KOPI (BEHA VIOR ACCESS INTERNET IN COFFEE SHOP). (2017). Jurnal Sosioteknologi.No.16(3).Bandung, Indonesia 259-264. http://dx.doi.org/10.5614\%2Fs ostek.itbj.2017.16.3.4

[7] R. Panuju. Communication note on Journal of Drug and Alcohol Research.( 2020). No.9 (1). Polandia. 1-2. https://doi.org/10.4303/jdar/e236090

[8] http://www.raudlatuljannah.sch.id/halaman-20-Kurikulum.html

[9] M. Ishak, Syafaruddin, M.Sit. PELAKSANAAN PROGRAM TILAW AH ALQURANDALAM MENINGKATKAN KEMAMPUAN MEMBACA ALQUR'AN SISW ADI MAS ALMA'SUM STABAT. (2017). Edu-Relegia.. No. 1 (4). Indonesia. 602-619. http://jurnal.uinsu.ac.id/index.php/eduriligia/article/view/1166

[10] D. Indriani \& A.I. Warnilah. SISTEM INFORMASI HAFALAN TERBAIK DALAM MUNAQOSAH TAHFIZHULQUR'AN MENGGUNAKAN METODE AHP. (2019) Evolusi. No. 7(1). Indonesia 1-11. https://doi.org/10.31294/evolusi.v7i1.5454

[11] A. Akhbar \& S.K. Riau. METODE TAHFIDZ AL-QUR'AN DI PONDOK PESANTREN KABUPATEN KAMPAR. (2016) Jurnal Usuluddin. No.24(1), Indonesia. 91-106. http://dx.doi.org/10.24014/jush.v24i1.1517

\section{BIO DATA}

Redi Panuju, Lektor Kepala (Associate Professor) in the Department of Communication Science, Dr. Soetomo University Surabaya, Indonesia. He was the Dean of the Faculty of Communication Science at his institution. Author of Sistem Penyiaran Indonesia (Indonesian Broadcasting System), Pengantar Studi Ilmu Komunikasi (The Introduction of Communication). He was once a Commissioner of the East Java Regional Indonesian Broadcasting Commis sion (20072016). Email: redipanuju [AT] gmail.com 